\title{
ボアホールジャッキ試験による 新たな岩盤初期応力の評価理論の提案
}

\author{
川久保 昌平 1 -村上 祐治 2 -長澤 寛和 3 - 谷 和夫 4 \\ 1正会員 株式会社安藤・間 建設本部技術研究所（†305-0822 茨城県つくば市荻間515-1） \\ E-mail: kawakubo.shohei@ad-hzm.co.jp \\ 2正会員 株式会社安藤・間 建設本部技術研究所（†305-0822 茨城県つくば市荻間515-1） \\ E-mail: murakami.yuji@ad-hzm.co.jp \\ 3非会員 株式会社安藤・間 建設本部技術研究所（干305-0822 茨城県つくば市苅間515-1） \\ E-mail: nagasawa.hirokazu@ad-hzm.co.jp \\ 4正会員 東京海洋大学教授 学術研究院（一108-8477 東京都港区港南4丁目 5番7号) \\ E-mail: ktani00@kaiyodai.ac.jp
}

\begin{abstract}
大深度地下岩盤に掘削される空洞の安定性を検討するには，岩盤の変形係数や初期応力を評価すること が必要となる。国内では原位置岩盤の初期応力測定には，主に水圧破砕法や応力解放法等が用いられてき た。しかし，これらの測定法は特殊な作業を伴うためコストや労力を要する.

一方，岩盤の変形係数を測定する有効な方法にボアホールジャッキ試験があり，岩盤の変形係数は載荷 圧力ー孔壁変位曲線の直線部分の傾きから算定される. 本研究では岩盤の初期応力が同じ曲線の切片から 求められることを理論的に明らかにした。同一試験から変形係数と初期応力が求められれば，従来の測定 法に対して効率化や低コスト化が図られる。本論文では同試験から初期応力を求める弾性理論及び大型コ ンクリート試験体を用いた室内実験によりその妥当性を確認した結果を示す.
\end{abstract}

Key Words : initial rock stress, borehole jack test, theoretical solution, back analysis

\section{1. 緒言}

地下大深度に掘削された空洞の安定性を評価するため には，岩盤物性とともに初期応力を測定することが重要 である。岩盤の初期応力を測定する場合，国内では水圧 破砕法や応力解放法等 1) 3)が適用されることが多く，こ れまでに多くの測定が行われてきた。このうち埋設ひず み法や円錐孔底ひずみ法等の応力解放法 1)44は，坑道内 からのボアホールを利用して行われることが多く, 施工 段階において有効な測定法である。しかし，これらは亀 裂や湧水のある区間では測定が困難である上，岩盤の剛 性を求めるために室内試験を行う必要がある等により,

一般にコストや労力がかかる. この問題に対し, ボアホ 一ルジャッキ試験によって初期応力が測定できれば，空 洞の安定性評価に必要な初期応力と岡性を同時に把握で きるため，測定効率やコス卜低減が図られることになる

そこで，本研究ではボアホールジャッキ試験 5),0に弾 性㛜密解を適用して，孔軸に直交する面内二軸の初期応 力を求める解析理論を整理した。著者は既に同試験に弾
性㛜密解を適用して, 変形係数の算定式 7) 9)を導出して いる. 本論文では弾性厳密解を用いて載荷初期圧と初期 応力との関係性を弾性論に基づいて明らかにした上で, 初期応力の逆解析方法を示した. また, 論文後半では実 験によって理論の妥当性を確認した.

\section{2. ボアホールジャッキ試験の概要}

\section{(1) 試験装置}

ボアホールジャッキ方式 5), のは金属製の載荷板を用い て孔壁を部分的に載荷するもので，古くから土質地盤か ら軟岩，硬岩まで広く適用されてきた。図-1に岩盤を対 象とした試験システムの構造例を, 図-2にボアホールジ ヤッキ試験の解析モデルを示す。図-1のシステムでは, 油圧ポンプで発生させた圧力を, 送り側の油圧ホースを 介して試験器本体に内蔵の小型油圧ジャッキに送ること で，ピストンを外側に押し出すようになっている．載荷 板は各ピストンと連結されていることから，油圧の 


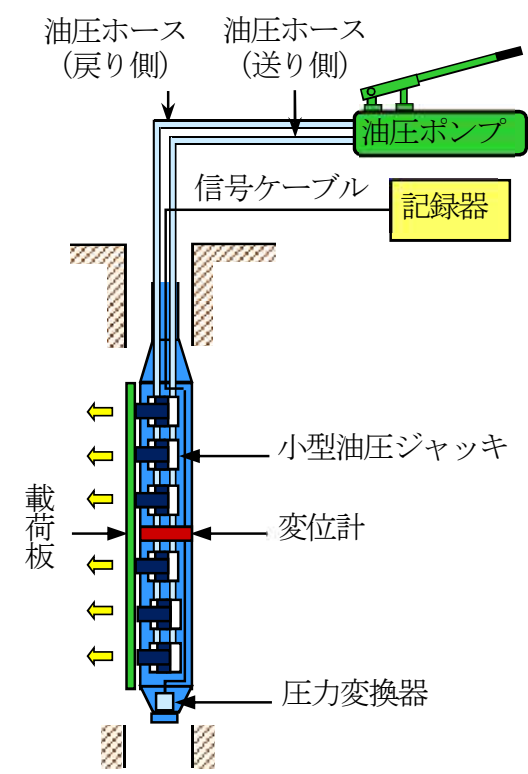

図-1ボアホールジャッキ試験のシステム構造

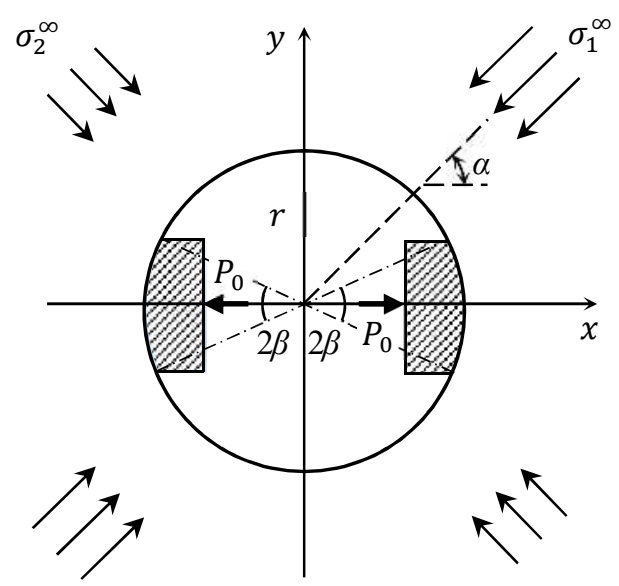

図-2 ボアホールジャッキ試験の解析モデル

増加とともに載荷板が開く、試験終了時には油圧ポンプ の切替弁を戻り側の油圧ホースに切り替えることでオイ ルが油圧ポンプに戻り, 載荷板を閉じることができる. 通常，岩盤を対象とする場合の載荷板は片開き方式であ り, 試験器の背面は載荷板と同じ曲率に加工されている か曲率が同じ背面板を設置するようになっている. 載荷 板及び背面板はボーリング孔径に合わせたものを取り付 ける.このようにして載荷試験によって得られた載荷圧 力と孔壁変位の線形関係（傾き）は $K$ 值と呼ばれ, 最終 的に変形係数は $K$ 值に弾性論によって導かれた定数等を 乗ずることによって算定される.

\section{(2) 変形係数算定の理論}

図-2に示寸ように，半径 $r$ のボアホールにおいて，中 心角度 $2 \beta$ の載荷板は孔壁と完全密着し, 載荷方向は $x$ 軸に一致していると仮定する. その状態で初期応力 $\sigma_{1}^{\infty}$ 及び $\sigma_{2}^{\infty}$ が $x$ 軸と $\alpha$ の角度で作用するとき, 載荷板には
表-1 各記号の定義

\begin{tabular}{|c|c|c|c|}
\hline 記号 & 定義 & 記号 & 定義 \\
\hline$r$ & ボアホール半径 & $\beta$ & 載荷角度の半分 \\
\hline$v$ & ポアソン比 & $\kappa$ & $3-4 v$ (平面ひずみ) \\
\hline$\gamma$ & $\ln \kappa / 2 \pi$ & $D(E)$ & 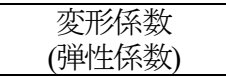 \\
\hline$P_{0}$ & 載荷初期合力 & $p_{0}$ & 載荷初期圧 \\
\hline$\sigma_{1}^{\infty}, \sigma_{2}^{\infty}$ & 最大 ・ 最小主応力 & $\alpha$ & $\sigma_{1}^{\infty}$ の作用角度 \\
\hline
\end{tabular}

対抗する合力 $P_{0}$ が生じる. このときの $P_{0}$ を載荷初期合 力, 載荷面積で除した $p_{0}$ を載荷初期圧と呼ぶことにす る.これらを含めた解析に用いる諸定数を表-1にまとめ て示す. 孔壁上の載荷板が接触する区間を境界 $L_{1}$, 非 接触区間を境界 $L_{2}$ とし， $u$ を孔壁の載荷方向（ $x$ 軸方向） 変位， $\sigma_{r}, \tau_{r \theta}$ を孔壁に作用する半径方向応力およびせ 几断応力と寸ると, 孔壁上での境界条件は式(1)の混合 境界として表される.

$$
\left.\begin{array}{lll}
u=\text { Const. } & \cdots & \text { on } L_{1} \\
\sigma_{r}=\tau_{r \theta}=0 & \cdots & \text { on } L_{2}
\end{array}\right\}
$$

この混合境界值問題に対する䩦密解は妻木ら ${ }^{10}$ により 導出されており，著者はこの解を用いて変形係数 $D$ （ま たは弾性係数 $E$ ）の算定式を以下の式(2)のように導出 した ${ }^{8)}$ 10)．なお， $D$ とEの違いであるが， $D$ は亀裂等の 不均質性を有する岩盤を巨視的に弾性体と捉えた場合の 弾性係数である ${ }^{5}$. 寸なわち亀裂を含まない岩盤, 岩石 及びコンクリート等による供試体では，両者は同一のも のとなる.

$$
\left.\begin{array}{c}
D \text { or } E=r \Phi(v, \beta) \frac{\Delta p}{\Delta u} \\
\Phi(v, \beta)=\kappa(1+v) \sin \beta e^{-\gamma \pi \frac{J_{0}^{\prime}}{J_{0}}}
\end{array}\right\}
$$

ここに, $v$ は岩盤のポアソン比で, $\Delta p / \Delta u$ は $K$ 值と呼ば れる. 定数 $\kappa, \gamma, J_{0}$ 及び $J_{0}^{\prime}$ は式(3), (4) で与えられる. 式(2)第二式における $\Phi(\nu, \beta)$ の数值は数表 9,9$)$ として整 理されており, 実際の変形係数や弾性係数の算定に活用 されている. なお， $\Phi(\nu, \beta)$ の数表は付録の表-A に示す.

$$
\left.\begin{array}{c}
\kappa=3-4 v, \quad \gamma=\frac{\ln \kappa}{2 \pi} \\
J_{0}=\int_{0}^{\beta} \frac{\cos \Theta_{1}(\theta)}{\Omega_{1}(\theta)} d \theta, \quad J_{0}^{\prime}=\int_{\beta}^{\frac{\pi}{2}} \frac{\cos \Theta_{2}(\theta)}{\Omega_{2}(\theta)} d \theta
\end{array}\right\}(3)
$$




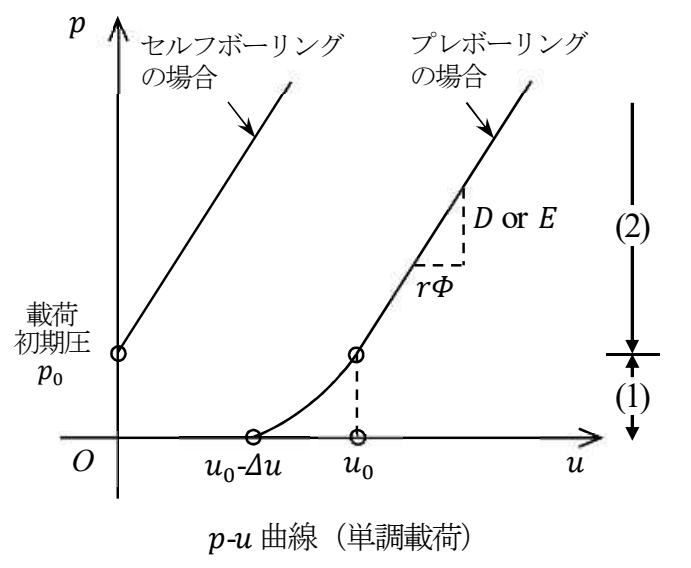

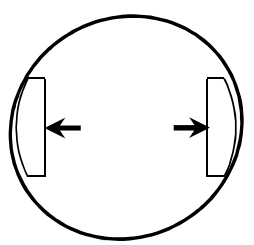

(1) 部分接触

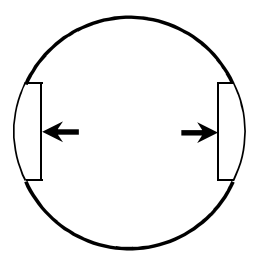

(2) 全面接触
図-3 載荷圧一孔壁変位曲線における 孔壁と載荷板の接触状況

\section{3. 初期応力測定理論}

\section{（1）載荷合力の理論式}

図-1 における載荷初期合力 $P_{0}$ は，妻木・山田の混合 境界值問題としての厳密解 ${ }^{10)}$ により, 次式で表される.

$$
P_{0}=\frac{2(1+\kappa)}{\kappa} \int_{0}^{\beta} \operatorname{Re}\left[\phi(\theta) e^{i \theta}\right] d \theta
$$

ここに,

$$
\begin{aligned}
& \phi(\theta)=X(\theta)\left(C_{2} e^{2 i \theta}+C_{0}+C_{-2} e^{-2 i \theta}\right) \\
& X(\theta)=-\frac{e^{\gamma(\pi+2 \beta)}}{2 \Omega_{1}(\theta)} e^{i\left\{\theta_{1}(\theta)-\theta\right\}}
\end{aligned}
$$

式(6) 中の $C_{0}, C_{ \pm 2}$ は初期応力等により次式で定まる定数 である.

$$
\begin{aligned}
C_{2}= & \frac{1}{4}\left(\sigma_{1}^{\infty}+\sigma_{2}^{\infty}\right) \\
C_{0}=-\frac{1}{2 I_{0}^{\prime}} & \left\{\left(\frac{I_{2}^{\prime}}{2}+e^{-4 \gamma \beta} I_{-2}^{\prime} e^{2 i \alpha}\right) \sigma_{1}^{\infty}\right. \\
& \left.+\left(\frac{I_{2}^{\prime}}{2}-e^{-4 \gamma \beta} I_{-2}^{\prime} e^{2 i \alpha}\right) \sigma_{2}^{\infty}\right\} \\
C_{-2}= & \frac{1}{2} e^{-4 \gamma \beta}\left(\sigma_{1}^{\infty}-\sigma_{2}^{\infty}\right) e^{2 \alpha}
\end{aligned}
$$

式(8)中の定数 $I_{0}^{\prime}, I_{ \pm 2}^{\prime}$ は次式で得られる.

$$
\left.\begin{array}{c}
I_{0}^{\prime}=e^{2 \gamma \beta} \int_{\beta}^{\frac{\pi}{2}} \frac{\cos \Theta_{2}(\theta)}{\Omega_{2}(\theta)} d \theta \\
I_{ \pm 2}^{\prime}=e^{2 \gamma \beta} \int_{\beta}^{\frac{\pi}{2}} \frac{\cos \left\{\Theta_{2}(\theta) \pm 2 \theta\right\}}{\Omega_{2}(\theta)} d \theta
\end{array}\right\}
$$

土木学会論文集C (地圈工学), Vol. 76, No. 3, 285-294, 2020.

\section{（2）載荷初期圧の力学的意味}

図-3に単調載荷の場合における載荷圧一孔壁変位曲線 （以下， $p-u$ 曲線）及び孔壁と載荷板の接触状況の模式 図を示した. プレボーリング方式 ので害施するボアホー ルジャッキ試験では, 載荷の初期段階において孔壁周辺 の緩みや載荷板と孔壁のなじみ等の影響により緩やかな 曲線を示寸 (同図(1)) . その後, 曲線は $p$ の増加ととも に線形性が高くなる（同図(2)）。式(2) は図-3(2) の状況 における線形関係を示寸ものであり， $D$ または $E$ は $K$ 值 に $r \Phi(\nu, \beta)$ を乗じて求められる ${ }^{5}{ }^{29} \cdot p_{0}$ は (1) から (2) 一 の変化点で, 接触孔壁を変形前状態に戻すのに要する圧 カである. もし, セルフボーリング方式 のよりボアホ ールジャッキ試験を実施したならば, $p-u$ 曲線は載荷初 期段階で曲線性を示すことなく, $p_{0}$ を切片とする直線 状となるであろう。実際は岩盤のボアホールジャッキ試 験を同方式で実施することは困難であるが，プレボーリ ング方式において $p_{0}$ は $p-u$ 曲線における (1), (2) の変化 点として見出すことができる.

\section{（3）初期応力と載荷初期圧の関係}

$p_{0}$ と $\sigma_{1}^{\infty}, \sigma_{2}^{\infty}$ 及び $\alpha$ との関係を導出する. まず, $p_{0}$ は $P_{0}$ と式(10)の関係にある.

$$
p_{0}=\frac{P_{0}}{2 r \sin \beta}
$$

式(5)（9) と式(10) から得られる関係式を $\sigma_{1}^{\infty}, \sigma_{2}^{\infty}$ につ いて整理すると， $p_{0}$ は最終的に次式として得られる.

$$
p_{0}=A_{1}(\alpha, \beta) \sigma_{1}^{\infty}+A_{2}(\alpha, \beta) \sigma_{2}^{\infty}
$$

ここに, $A_{1}(\alpha, \beta)$ 及び $A_{2}(\alpha, \beta)$ は $\sigma_{1}^{\infty}, \sigma_{2}^{\infty}$ に対する感度 係数で, 次式で表される.

$$
\left.\begin{array}{l}
A_{1}(\alpha, \beta)=L \int_{0}^{\beta} \frac{g_{2}(\theta)}{\Omega_{2}(\theta)} d \theta \\
A_{2}(\alpha, \beta)=L \int_{0}^{\beta} \frac{g_{-2}(\theta)}{\Omega_{2}(\theta)} d \theta
\end{array}\right\}
$$

$$
\left.\begin{array}{rl}
g_{ \pm 2}(\theta) & =\cos \Theta_{2}(\theta)\left(\frac{1}{2} \pm e^{-4 \gamma \beta} \cos 2 \alpha\right) \cos 2 \theta \\
& -\sin \Theta_{2}(\theta)\left(\frac{1}{2} \mp e^{-4 \gamma \beta} \cos 2 \alpha\right) \sin 2 \theta \\
& -\cos \Theta_{2}(\theta) \frac{1}{I_{0}^{\prime}}\left(\frac{I_{2}^{\prime}}{2} \pm e^{-4 \gamma \beta} I_{-2}^{\prime} \cos 2 \alpha\right)
\end{array}\right\}
$$

式(2)の第一式を増分形式から通常表記に戻し, 式(11) と重㸚わせると $p$ は次式となる。

$$
p=p_{0}+\frac{D \text { or } E}{r \Phi(v, \beta)} u
$$

この式は図-3のセルフボーリングにおける $p-u$ の線形関 係を表すものである. 右辺第一項は切片として初期応力 と，第二項は傾きとして $D$ または $E$ とそれぞれ関係す ることを示している. 


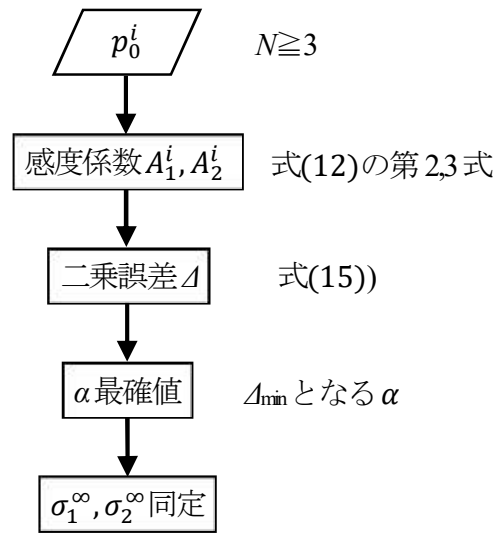

図-4 初期応力を求める逆解析のフロー

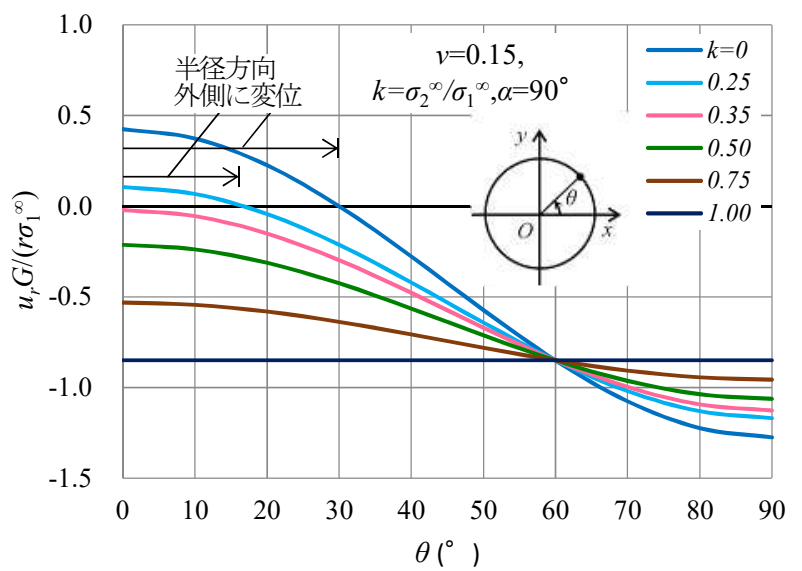

図-5 孔壁変位

\section{4. 初期応力の逆解析方法}

\section{（1）最小二乗法による逆解析}

試験で得られた $p_{0}$ から，孔軸に直交する面内の初期 応力を逆解析する方法を述べる. 二軸方向の初期応力に 対する未知量は大きさと方向の 3 つであり, 入力值とし ての $p_{0}$ は最低 3 つ必要となる. 今, 載荷方向を変えて $N$ 回の試験を行ったとし，誤差関数 $\Delta$ を次式で定義する.

$$
\Delta=\sum_{i}^{N}\left\{p_{0}^{i}-L\left(A_{1}^{i} \sigma_{1}^{\infty}+A_{2}^{i} \sigma_{2}^{\infty}\right)\right\}^{2}
$$

上添字は $i$ 回目の測定であることを示す. $\Delta$ を $\sigma_{1}^{\infty}, \sigma_{2}^{\infty}$ でで偏微分したものを 0 とすることにより，式(16)の正 規方程式が導かれる. $\sigma_{1}^{\infty}, \sigma_{2}^{\infty}$ はこれを解くことで求め られる. $\alpha$ は $A_{1}^{i}, A_{2}^{i}$ に含まれ陽な形式で表すことができ ないため, $-\pi / 2 \sim \pi / 2$ の範囲で与えて $\Delta$ が最小となる ものを $\alpha$ の最確值とする. 図-4 に逆解析フローを示す.

$$
L\left[\begin{array}{ll}
\sum_{i=1}^{N} A_{1}^{i^{2}} & \sum_{i=1}^{N} A_{1}^{i} A_{2}^{i} \\
\sum_{i=1}^{N} A_{1}^{i} A_{2}^{i} & \sum_{i=1}^{N} A_{2}^{i^{2}}
\end{array}\right]\left[\begin{array}{l}
\sigma_{1}^{\infty} \\
\sigma_{2}^{\infty}
\end{array}\right]=\left[\begin{array}{l}
\sum_{i=1}^{N} p_{0}^{i} A_{1}^{i} \\
\sum_{i=1}^{N} p_{0}^{i} A_{2}^{i}
\end{array}\right]
$$

\section{(2) 適用限界}

図-5 はボアホールを削孔し，初期応力のみの作用下 $(p=0)$ で円孔上半径方向変位 $u_{r}(r$ 方向外側を正）を 弾性解 ${ }^{11)}$ により計算したものである。図中縦軸の $G$ はせ ん断弾性係数 $(=E / 2(1+v))$ である. この図より側 圧比 $k\left(=\sigma_{2}^{\infty} / \sigma_{1}^{\infty}\right)$ が0では $\theta<30^{\circ}$ で, $k=0.25$ では $\theta<17^{\circ}$ で $u_{r}>0$ となり，初期孔壁位置より外側に変 位する. この現象は $v$ を変化させても同じで， $k<$ 0.35 の場合に生じる. 提案する手法では，孔壁を加圧 して初期位置に押し戻すことを前提としているため, $u_{r}<0$ となる $k \geqq 0.35$ の場合を適用範囲とする.

\section{5. 実証実験}

コンクリート製の試験体を模擬岩盤として，初期応力 の測定理論とその解析方法の妥当性を検証するために実 証実験を行った.

\section{(1) 試験方法 \\ a) 試験体の作製}

表-2 に示寸配合のコンクリートにより，試験体を寸法 $1 \mathrm{~m} \times 1 \mathrm{~m} \times 0.5 \mathrm{~m}$ で作製した。試験体には図-6のように予 め埋設型ひずタゲージ（(株)東京測器研究所製, KM100B）を設置し，実験時には変位計および表面ひずみ 計を設置した。試験体は打設後に $\phi 66 \mathrm{~mm}$ のボアホール を削孔した．打設から 28 日経過後，打設時に作製した 直径 $100 \mathrm{~mm}$, 高さ $200 \mathrm{~mm}$ の供試体により材料試験を実 施した。表-3はその試験結果である.

b) 荷重ケース

表-4 に外荷重の設定条件（Case1, 2,3）を示す. 写真1(a)は試験装置の全景である. 同写真では左上の反力壁 側が北(N) となっている。試験体の外側面に載荷する外 荷重は，主方向（NS 方向）として $1.0 \mathrm{MPa}(500 \mathrm{kN})$ に固定 し，その直交方向（EW 方向）には 0.5, 0.8, 1.0 MPa (250, $400,500 \mathrm{kN})$ とする 3 ケースを設定し，それらをCase1, 2, 3 とした. ボアホールジャッキ試験の開始前に外荷重は油 圧ジャッキを用いて約 30 分かけて所定值に達するよう にした. 載荷面と油圧ジャッキの間には鋼材を介した. 外荷重増加に伴う埋設ひずみの值を Case1 を例として図7 に示した. 縦軸は NS 方向のゲージに対しては同方向 の荷重を，EW 及び斜め方向のゲージに対しては EW 方 向の荷重を示す．載荷面でのなじみの影響もあり，ひず みが急激変化しているところもあるが，最終的に埋設ひ ずみ計の $\mathrm{S}, \mathrm{NE}, \mathrm{E}$ 及び $\mathrm{W}$ のひずみは理論值に近付い た. SW のひずみは感度が悪く, 局所的に応力が十分伝 達されなかったものと思われる. 
表-2 試験体コンクリートの配合

\begin{tabular}{|c|c|c|c|c|c|c|c|c|c|c|}
\hline \multirow{3}{*}{$\begin{array}{l}\text { 粗骨 } \\
\text { 材最 } \\
\text { 大径 } \\
(\mathrm{mm})\end{array}$} & \multirow{3}{*}{$\begin{array}{l}\text { スラ } \\
\text { ンプ } \\
(\mathrm{cm})\end{array}$} & \multirow{3}{*}{$\begin{array}{l}\text { 空気 } \\
\text { 量 a } \\
(\%)\end{array}$} & \multirow{3}{*}{$\begin{array}{l}\text { 水セメ } \\
\text { ント比 } \\
\mathrm{W} / \mathrm{C} \\
(\%)\end{array}$} & \multirow{3}{*}{$\begin{array}{c}\text { 細骨材 } \\
\text { 率 s/a } \\
(\%)\end{array}$} & \multicolumn{6}{|c|}{ 単位量 $\left(\mathrm{kg} / \mathrm{m}^{3}\right)$} \\
\hline & & & & & \multirow{2}{*}{$\begin{array}{l}\text { 水 } \\
\mathrm{W}\end{array}$} & \multirow{2}{*}{$\begin{array}{l}\mathrm{C} \text { (普通 } \\
\text { ポルト } \\
\text { ランド) }\end{array}$} & \multicolumn{2}{|c|}{ 細骨材 s } & \multirow{2}{*}{$\begin{array}{l}\text { 粗骨 } \\
\text { 材 } \mathrm{G}\end{array}$} & \multirow{2}{*}{$\begin{array}{c}\text { 混和 } \\
\text { 剂 }\end{array}$} \\
\hline & & & & & & & (1) & (2) & & \\
\hline 20 & 12 & 4.5 & 100 & 100 & 172 & 172 & 617 & 277 & 1,038 & 2,580 \\
\hline
\end{tabular}

表-3 材料諸元（28 日材齢）

\begin{tabular}{|c|c|c|c|c|}
\hline $\begin{array}{c}\text { 密度 } \\
\left(\mathrm{Mg} / \mathrm{m}^{3}\right)\end{array}$ & $\begin{array}{c}\text { 弾性 } \\
\text { 係数 } \\
(\mathrm{MPa})\end{array}$ & $\begin{array}{c}\text { 圧縮 } \\
\text { 強さ } \\
(\mathrm{MPa})\end{array}$ & $\begin{array}{c}\text { 圧裂 } \\
\text { 強さ } \\
(\mathrm{MPa})\end{array}$ & $\begin{array}{c}\text { ポアソン } \\
\text { 比 } \\
v\end{array}$ \\
\hline \hline 2.29 & $2.21 \times 10^{4}$ & 11.26 & 1.27 & 0.15 \\
\hline
\end{tabular}

表-4 外荷重ケース

\begin{tabular}{|c|c|c|c|}
\hline Case & $\begin{array}{c}\sigma_{1}^{\infty} \\
(\mathrm{MPa})\end{array}$ & $\begin{array}{c}\sigma_{2}^{\infty} \\
(\mathrm{MPa})\end{array}$ & $\begin{array}{c}\alpha \\
\left({ }^{\circ}\right)\end{array}$ \\
\hline \multirow{2nnn}{*}{1} & \multirow{3}{*}{1.0} & 0.5 & \multirow{3}{*}{90} \\
2 & 0.8 & \multirow{2}{*}{90} \\
\cline { 1 - 1 } 3 & & 1.0 & \\
\hline
\end{tabular}

表-5 孔内載荷試験シリーズ

\begin{tabular}{|c|c|}
\hline \multirow{3}{*}{ シリーズ } & $\begin{array}{c}\text { 載荷方向 } \\
(\circ)\end{array}$ \\
\hline \multirow{4}{*}{1} & 90 \\
\cline { 2 - 2 } & 45 \\
\cline { 2 - 2 } & 0 \\
\cline { 2 - 2 } & -45 \\
\hline \multirow{4}{*}{2} & 70 \\
\cline { 2 - 2 } & 25 \\
\cline { 2 - 2 } & -20 \\
\cline { 2 - 2 } & -65 \\
\hline
\end{tabular}

表-6 ボアホールジャッキ試験器の仕様

\begin{tabular}{|c|c|c|c|c|c|}
\hline \multirow{2}{*}{$\begin{array}{l}\text { 外径 } \\
\times \text { 長さ } \\
(\mathrm{mm})\end{array}$} & \multirow{2}{*}{$\begin{array}{c}\text { 載荷板 } \\
\text { 幅×長さ } \\
\text { (mm) }\end{array}$} & \multirow{2}{*}{$\begin{array}{c}\text { ピㅈン } \\
\text { 자ローク } \\
(\mathrm{mm})\end{array}$} & \multirow{2}{*}{$\begin{array}{c}\text { 最大 } \\
\text { 加圧力 } \\
(\mathrm{MPa})\end{array}$} & \multicolumn{2}{|c|}{ 測定精度 } \\
\hline & & & & $\begin{array}{l}\text { 圧力 } \\
(\mathrm{MPa})\end{array}$ & $\begin{array}{l}\text { 変位 } \\
(\mathrm{mm})\end{array}$ \\
\hline $65 \times 1000$ & $30 \times 250$ & 10 & 20 & 0.1 & 0.001 \\
\hline
\end{tabular}

\section{c) 載荷パターン}

ボアホールジャッキ試験の最大圧力は外荷重の 3 倍の $3.0 \mathrm{MPa}$ とした. 圧力ステップは $p_{0}$ を精度良く読み取る ため，圧力測定精度限界の $0.1 \mathrm{MPa}$ とした載荷形式は $p_{0}$ の読取りをしやすくするため単調載荷とした（図-8）。 予備試験で各圧力段階での変位は $30 \mathrm{~s}$ 以内で落ち着くこ とが確認されたことから，各圧力段階での測定時間は $30 \mathrm{~s}$ とした。上より, 載荷速度は $\Delta p / \Delta t=0.1 / 0.5=$ $0.2 \mathrm{MPa} / \mathrm{min}$ と設定した. ボアホールジャッキ試験は $45^{\circ}$ 間隔で 4 回実施するものを 1 シリーズとし，合計 2 シリ ーズ実施した．表-5に各シリーズで設定した載荷方向を 示す. 表-6 は試験器の仕様，写真-1(b)は測定状況である.

\section{(2) 試験結果}

$p-u$ 関係は曲線区間と直線区間に区分されるが，実験 データからは直線区間はさらに 2 区間に区分できる場合

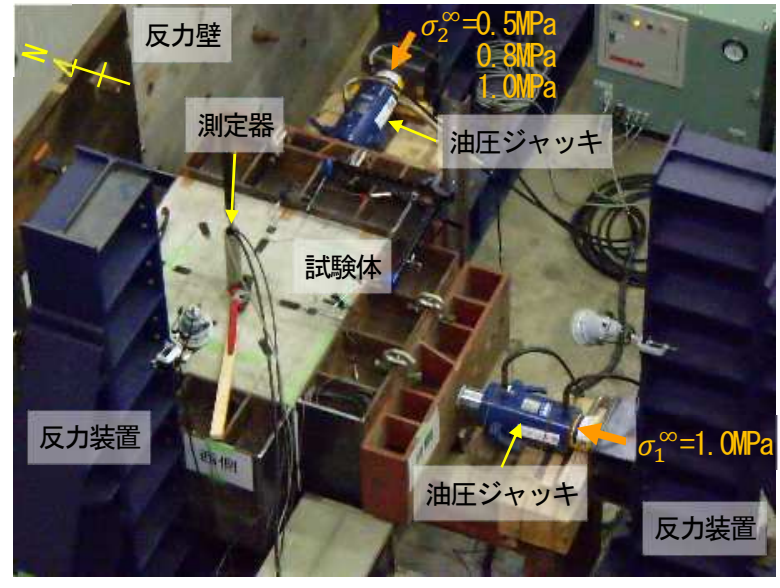

(a) 装置全景

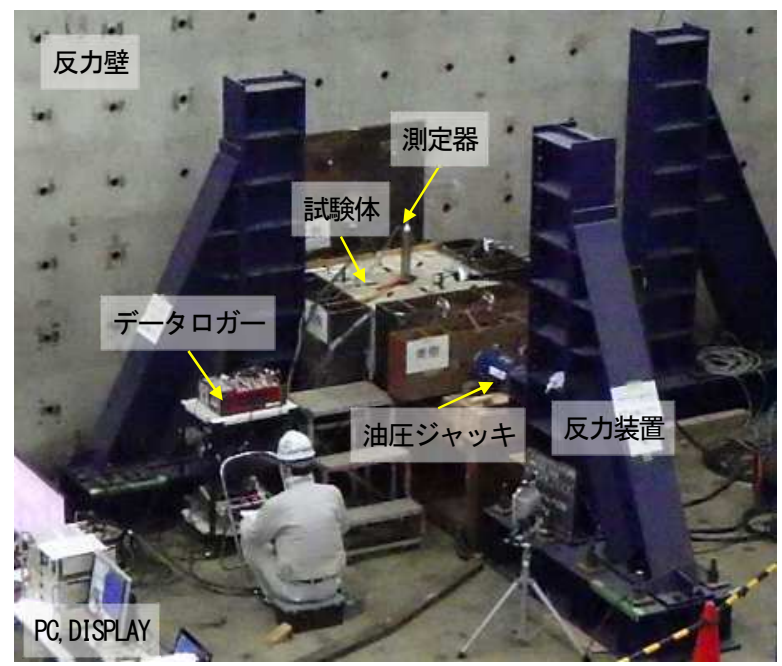

(b) 測定状況

写真-1 実験装置と実施状況

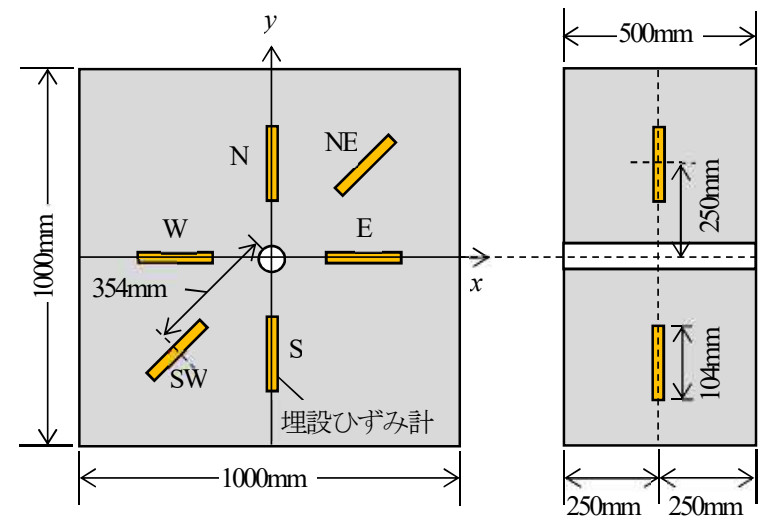

図-6 試験体の寸法と埋設ひずみ計の配置

が多かった。これらを区間 I， II，III とし，各々の特徵を 表-7 及び図-9 にまとめた. I は載荷板と孔壁の接触面が 増大する段階，II は密着後に初期孔壁位置までの変位段 階 $\left(p<p_{0}\right)$, III は初期の孔壁位置を超えた変形段階 $\left(p \geqq p_{0}\right)$ である. II から III への移行時圧力が $p_{0}$ となる.

図-10〜13 のそれぞれ(a)は Case 1, シリーズ 1 におい て $p-u$ 曲線を I〜III に区切り, 各交点を求めたものであ る. 同図のそれぞれ(b)は，(a)の一次導関数 $\Delta p / \Delta u$ を表 


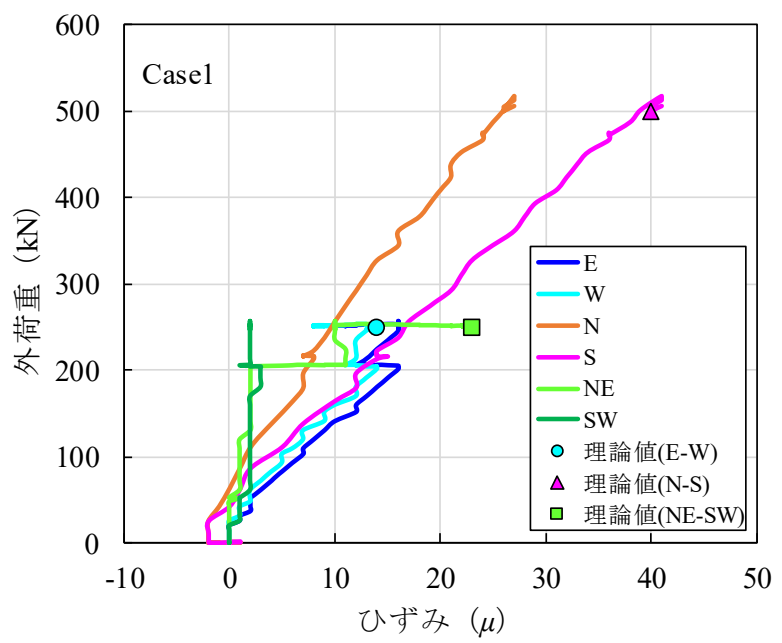

図-7Ｃase1の埋設ひずみ計データ

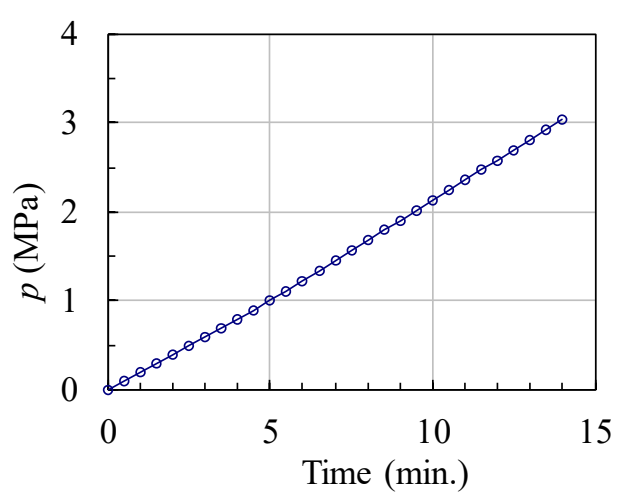

図-8 単調載荷パターン

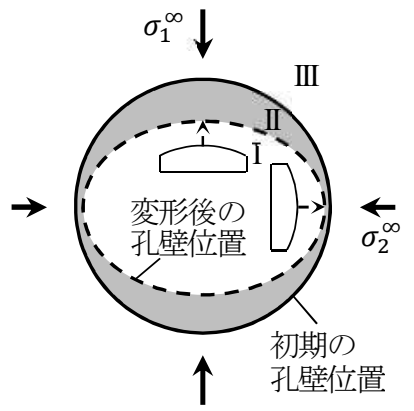

(a) I IIII 概念図

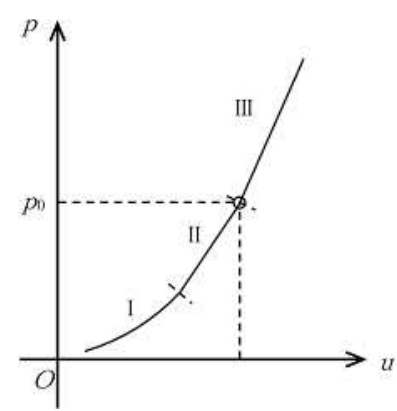

(b) I I III $の$ 区分
図-9 載荷初期段階の概念図

したものである. 区間の区切り方は(b)の $\Delta p / \Delta u$ の変化 に着目して決定した. $\Delta p / \Delta u$ は数值微分の 5 点データ を用いた中心差分法によって求めた。 なお，これら図中 の測定点横の数字はデータ No.を示し, 着色した測定点 は最小二乗法で用いたデータの区間端点を示寸．表-8は $\Delta p / \Delta u$ の II，III の区間平均值である.

図-10(b)では $\Delta p / \Delta u$ が No.4-10 でほぼ一定勾配と見な せることからこの区間をIとした。一方，No.16以降では 振動する点を除いて $\Delta p / \Delta u$ が一定に近くなっている.
表-7 $\quad p-u$ 曲線の載荷初期段階での特徵

\begin{tabular}{|c|c|}
\hline 区間 & 解説 \\
\hline I & 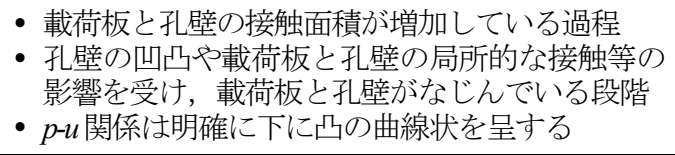 \\
\hline II & $\begin{array}{l}\text { ・載荷板が孔壁に密着して, 初期状態に戻してい } \\
\text { る過程 }\left(p<p_{0}\right) \\
\text { ・初期応力の最小主方向に近い載荷の場合は判別 } \\
\text { できないことがある(図-15(b) : B タイプ) } \\
\text { ・ p-u関係はほぼ直線状を呈す }\end{array}$ \\
\hline III & $\begin{array}{l}\text { ・ } p \geqq p_{0} \text { での載荷過程 } \\
\text { ・弾性変形内での載荷段階 } \\
\text { ・ } p-u \text { 関係は直線状を示し, 勾配は II よりも大 } \\
\text { ・変形係数を算定する区間 }\end{array}$ \\
\hline
\end{tabular}

しかし，No.16 付近で II， III の明確な区分は難しいため, この付近の点を除いて直線決定したところ，No.17-18 間 で交点となったため，これをII，IIIの境界とした．

図-11(b)では No.10〜16 区間が特異点（No.11,14）を除 きほぼ一定と見なした．また，No.18以降でも $\Delta p / \Delta u$ が 一定であることから，No.9-10間及びNo.16-17間を区間境 界とした. ここでも II，III の区分は No.17 付近で難しい が，仮にNo.17を除いて III の直線決定をした場合の交点 は $p=1.61$ となり，図-11(a)の No.17 を含めた場合とほぼ 同じとなる. 同図の場合は II から III への移行点が $p_{0}$ と なる.

一方，図-12(b)では $\Delta p / \Delta u$ が No.8 以降であまり変化 がない．今仮に No.15-16 間を境界とすると，II と III の $\Delta p / \Delta u$ の差は表-6 に見るように $2.7 \mathrm{MPa} / \mathrm{mm}$ と非常に小 さい.これは変形係数 $D$ の算定においては $100 \mathrm{MPa}$ 程度 の差にしかならず，有意な差とは見なせない。したがっ て，(II)はIIIに含まれるものとし，Iから III几の移行点を $p_{0}$ とする（I との交点は，境界付近の No.7を除いて算定 した結果得られた）。図-13(b)では, $\Delta p / \Delta u$ が No.8-13 及び No.18 以降で概ね一定と見なした．表-6 より II，III の差は有意であると判断し， II から III への移行点を $p_{0}$ とした.

\section{(3) 応力の逆解析}

表-9 に $p_{0}$ の理論值と実験による読取り值をまとめた. この值を用いて応力の逆解析を行った $(v=0.15, \beta$ =27.5 とした）. 表-10 及び図-14 に逆解析結果を示寸. Case1 ではシリーズ 1 が設定值と一致しており, シリー ズ 2 では $\sigma_{2}^{\infty}$ と $\alpha$ に設定值との差異が見られる. Case 2 ではシリーズ 1,2 ともに $\sigma_{1}^{\infty}, \sigma_{2}^{\infty}$ は設定值と一致している が， $\alpha$ はシリーズ 1 で差異が見られる. Case3 は静水圧状 態であるから $\alpha$ は無視してよく $, \sigma_{1}^{\infty}, \sigma_{2}^{\infty}$ はシリーズ 1,2 ともに比較的設定值に近い值が得られている. なお, 標 準偏差はどのケース及びシリーズでも 0.1 以下となった. 


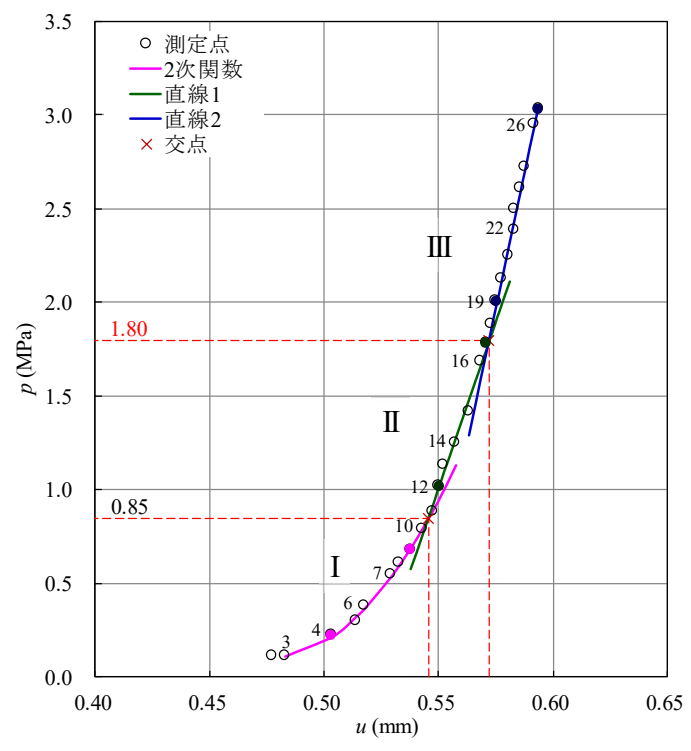

(a) 交点の解析

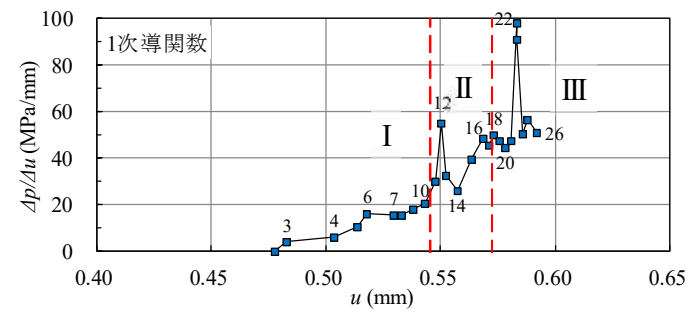

(b) 一次導関数の変化

図-10 Case1：載荷方向 $90^{\circ}$

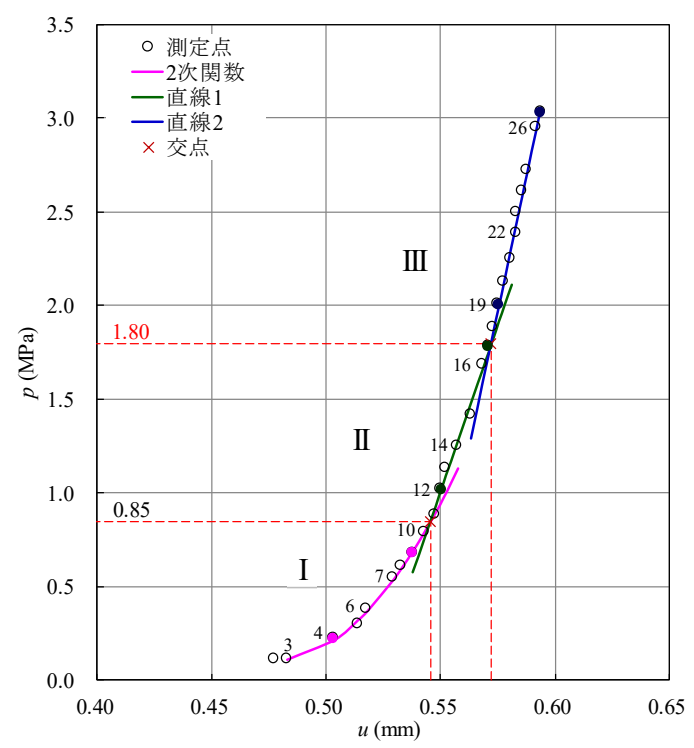

(a) 交点の解析

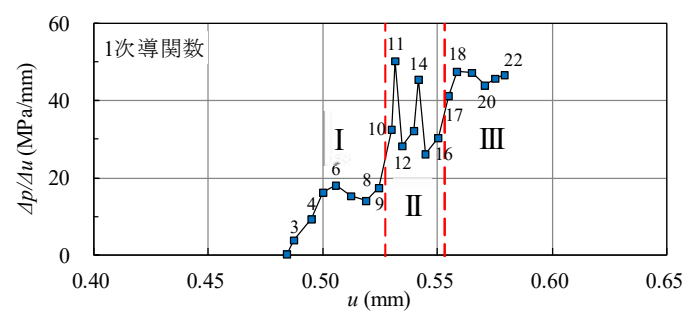

(b) 一次導関数の変化

図-11 Case1 : 載荷方向 $45^{\circ}$

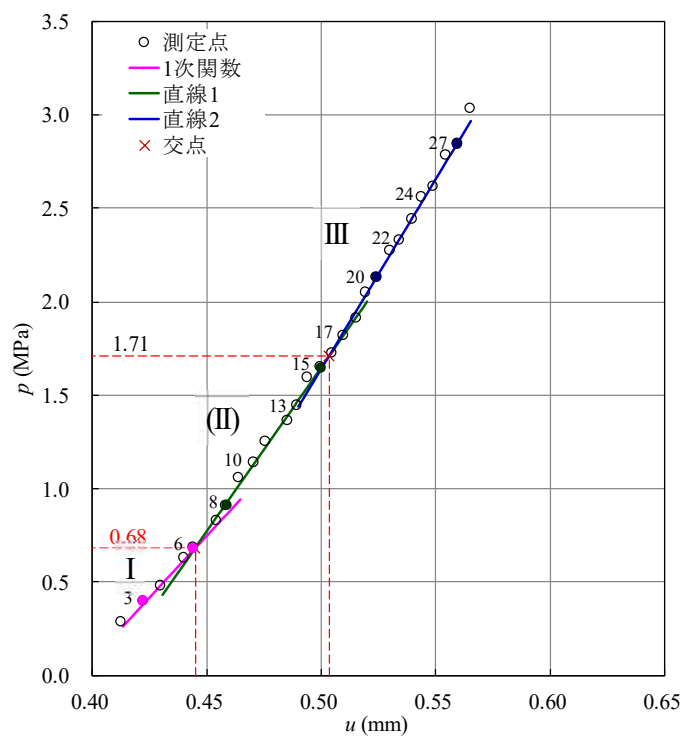

(a) 交点の解析

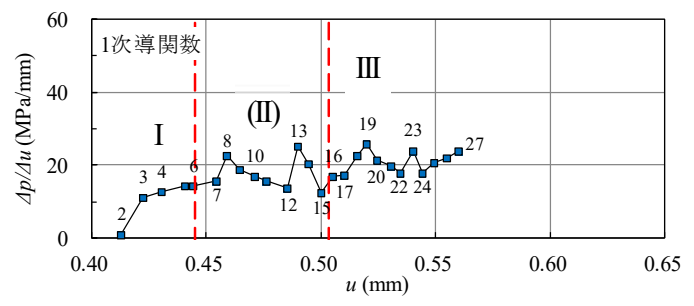

(b) 一次導関数の変化

図-12 Case1：載荷方向 $0^{\circ}$

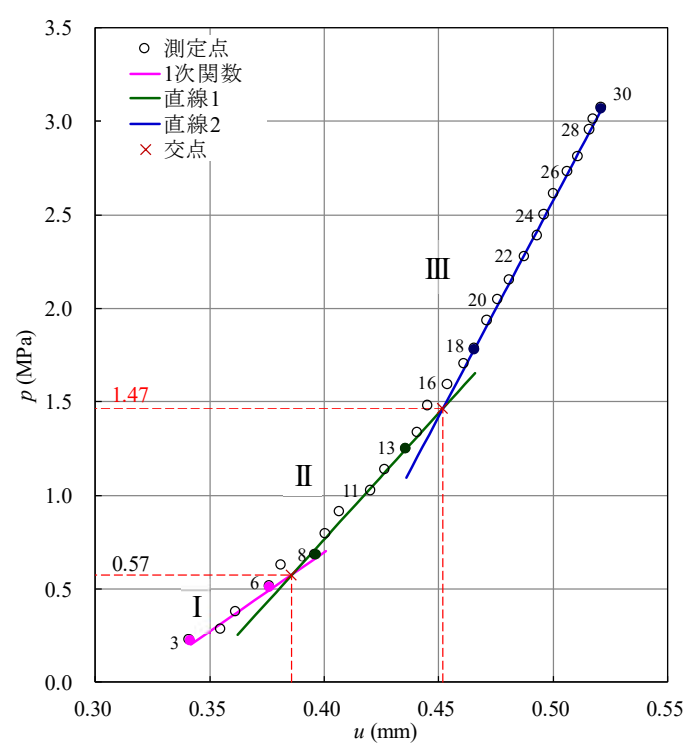

(a) 交点の解析

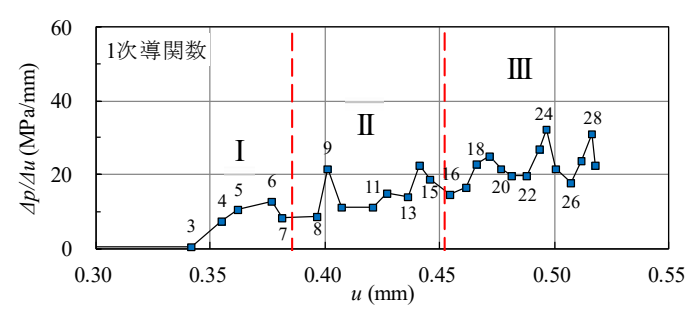

(b) 一次導関数の変化

図-13 Case1: 載荷方向 $45^{\circ}$ 
表-8 II, III 区間の $\Delta p / \Delta u$ 平均值

\begin{tabular}{|r||c|c|c|}
\hline \multicolumn{1}{|c||}{$\begin{array}{c}\text { 載荷 } \\
\text { 方向 }\end{array}$} & \multicolumn{1}{|c|}{$\Delta p / \Delta u(\mathrm{MPa} / \mathrm{mm})$} & \multirow{2}{*}{ 対応図 } \\
\cline { 2 - 3 } & II & \multicolumn{1}{|c|}{ III } & \\
\hline $90^{\circ}$ & 35.7 & 60.0 & 図-10 \\
\hline $45^{\circ}$ & 31.1 & 46.2 & 図-11 \\
\hline $0^{\circ}$ & 17.6 & 20.3 & 図-12 \\
\hline$-45^{\circ}$ & 13.4 & 23.0 & 図-13 \\
\hline
\end{tabular}

表-9 $p_{0}(\mathrm{MPa})$ の理論值と実験值

\begin{tabular}{|c|c|c|c|c|c|c|c|}
\hline \multirow{2}{*}{\multicolumn{2}{|c|}{$\begin{array}{l}\text { 載荷 } \\
\text { 方向 }\end{array}$}} & \multicolumn{2}{|c|}{ Casel $(k=0.5)$} & \multicolumn{2}{|c|}{ Case2 $(k=0.8)$} & \multicolumn{2}{|c|}{ Case3 $(k=1.0)$} \\
\hline & & \multirow{2}{*}{ 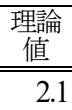 } & \multirow{2}{*}{$\begin{array}{c}\begin{array}{c}\text { 実験 } \\
\text { 值 }\end{array} \\
1.8\end{array}$} & \multirow{2}{*}{$\begin{array}{c}\begin{array}{c}\text { 理論 } \\
\text { 值 }\end{array} \\
2.0\end{array}$} & \multirow{2}{*}{ 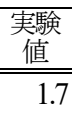 } & $\begin{array}{c}\text { 理論 } \\
\text { 值 } \\
\end{array}$ & \multirow{2}{*}{$\begin{array}{r}\begin{array}{c}\text { 実験 } \\
\text { 值 }\end{array} \\
1.7\end{array}$} \\
\hline \multirow{4}{*}{$\begin{array}{c}\text { シリ } \\
\text { ース } \\
1\end{array}$} & $90^{\circ}$ & & & & & \multirow{4}{*}{1.9} & \\
\hline & $45^{\circ}$ & 1.4 & 1.6 & 1.7 & 1.5 & & 1.7 \\
\hline & $0^{\circ}$ & 0.7 & 0.7 & 1.4 & 1.3 & & 1.5 \\
\hline & $-45^{\circ}$ & 1.4 & 1.4 & 1.7 & 1.8 & & 1.6 \\
\hline \multirow{4}{*}{$\begin{array}{l}\text { シリ } \\
\text { ーズ } \\
2\end{array}$} & $70^{\circ}$ & 2.0 & 1.7 & 1.9 & 2.0 & \multirow{4}{*}{1.9} & 1.8 \\
\hline & $25^{\circ}$ & 1.0 & 1.9 & 1.5 & 1.6 & & 2.1 \\
\hline & $-20^{\circ}$ & 0.9 & 1.2 & 1.5 & 1.5 & & 2.0 \\
\hline & $-65^{\circ}$ & 1.9 & 1.9 & 1.9 & 1.9 & & 1.8 \\
\hline
\end{tabular}

表-10 初期応力の逆解析結果

\begin{tabular}{|c|c|c|c|c|c|c|}
\hline & $\begin{array}{c}\sigma_{1}^{\infty} \\
(\mathrm{MPa})\end{array}$ & $\begin{array}{c}\sigma_{2}^{\infty} \\
(\mathrm{MPa})\end{array}$ & $\begin{array}{l}\alpha \\
\left({ }^{\circ}\right)\end{array}$ & $\begin{array}{c}\Delta \\
(\mathrm{MPa})\end{array}$ \\
\hline \multirow{3}{*}{$\begin{array}{c}\text { Case } \\
1\end{array}$} & \multicolumn{2}{|c|}{ 設定値 } & 1.0 & 0.5 & 90 & - \\
\hline & \multirow{2}{*}{ 逆解 } & シリーズ 1 & 0.9 & 0.5 & 85 & $5.9 \times 10^{-2}$ \\
\hline & & シリーズ 2 & 1.0 & 0.8 & 74 & $1.9 \times 10^{-1}$ \\
\hline \multirow{3}{*}{$\begin{array}{c}\text { Case } \\
2\end{array}$} & \multicolumn{2}{|c|}{ 設定值 } & 1.0 & 0.8 & 90 & - \\
\hline & \multirow{2}{*}{ 逆解 } & シリーズ 1 & 1.0 & 0.8 & 108 & $2.1 \times 10^{-2}$ \\
\hline & & シリーズ2 & 1.0 & 0.8 & 86 & $6.2 \times 10^{4}$ \\
\hline \multirow{3}{*}{$\begin{array}{c}\text { Case } \\
3\end{array}$} & \multicolumn{2}{|c|}{ 設定値 } & 1.0 & 1.0 & - & - \\
\hline & \multirow{2}{*}{ 逆解 } & シリーズ 1 & 0.9 & 0.8 & 79 & $2.0 \times 10^{-3}$ \\
\hline & & シリーズ 2 & 1.1 & 1.0 & 7 & $9.5 \times 10^{4}$ \\
\hline
\end{tabular}

$※ \sigma_{1}^{\infty}, \sigma_{2}^{\infty}$ の標準偏差はいずれも $0.1 \mathrm{MPa}$ 以下である

\section{6. 実験結果の考察}

(1) $p-u$ 曲線 における区間区分と各区間の特徵

I 区間 : $p-u$ 曲線では緩やかな曲線状を呈し, $p$ の増大 と共に線形になる。区間判別には， $\Delta p / \Delta u$ が増大し一 定值に漸近する区間に着目する. II との交点算定では, 図-12,13 のように便宜上直線近似した方がよい場合があ る.

II 区間 : $\Delta p / \Delta u$ は概ね一定であるが，振幅が III よりも やや大きい傾向にある. 圧力レベルが III よりも低いた め, 実験では粗骨材の挙動が反映された可能性が高い.

III 区間： $\Delta p / \Delta u$ は II と同様振動する場合があるが，平 均的には II より大きく一定に近い. II との判別は表-8の ように, $\Delta p / \Delta u$ の平均值から定量的に判断ができる.

\section{(2) 区分のタイプ}

載荷初期段階における I III への区分タイプを図-15に 示す $\mathrm{A}, \mathrm{B}$ とした. 区間 II が見られなかった $\mathrm{B}$ タイプの $p$
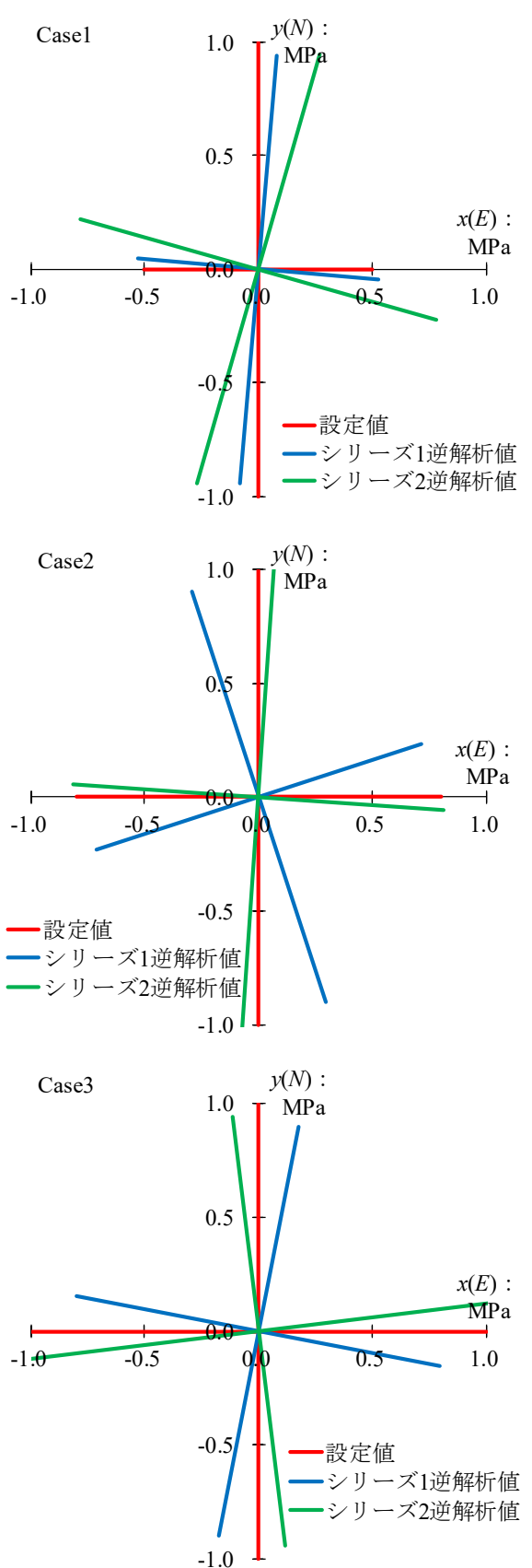

図-14 各ケースの応力逆解析結果と設定值の比較

$-u$ 曲線は, Case 1 で載荷方向が $0 \circ$ の場合であった. Case 1 は側圧比 $k$ が 0.5 の場合である. 一方, Case 2 及びCase 3 は側圧比が $0.8,1.0$ であり, $p-u$ 曲線区分は A タイプの みであった。図-9(a) に示すように, 最小主応力方向に 載荷する場合には，孔壁が初期状態に戻るまでの変位量 は小さいため, Case 1 の $0^{\circ}$ 方向の載荷では II が確認され なかったと考えられる. $k$ が 0.5 程度以下の場合にはこ のような現象が生じるものと推測される.

\section{(3) 区間区分上の留意点}

$\Delta p / \Delta u$ から定量的に区間区分するためには最小二乗 法によって曲線及び直線を決定する. その際, $\Delta p / \Delta u$ が大きく振動する点は除き（図-10(b) の No.22や図-11(b) 

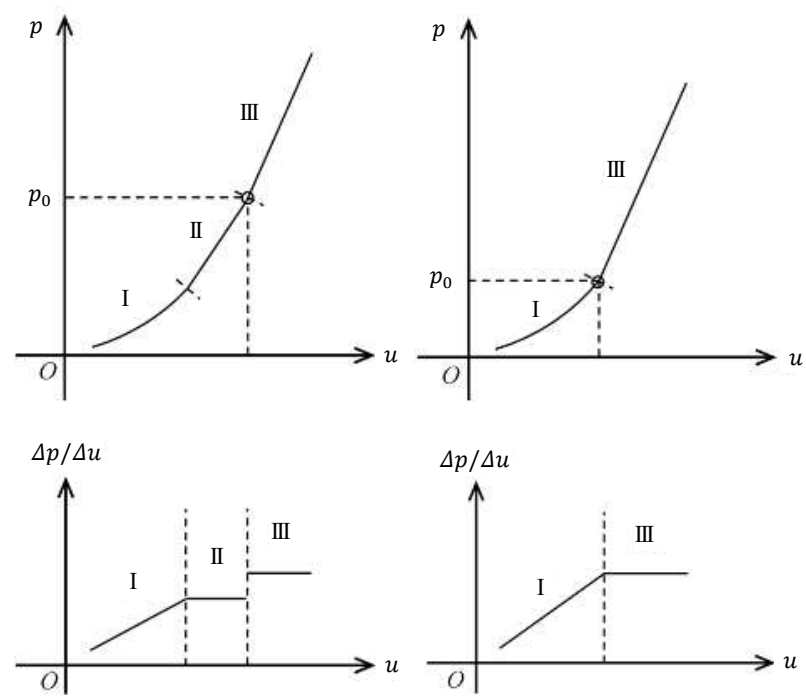

(a) Aタイプ：一般的な場合

(b) $\mathrm{B}$ タイプ: $\sigma_{2}^{\infty}$ 方向付近 で載荷の場合

図-15 載荷初期段階の区分タイプ

の No.11, No.14），5 点程度がほぼ同じであれば一定と判 断する. $\Delta p / \Delta u$ が小刻みに振動する場合には，振幅の 中心を平均值として評価する（図-13 の III）。A, B の夕 イプ分けでは，表-8のように $\Delta p / \Delta u$ の区間平均值から, II,III の区分が有意であるかを見極めて判断する.

\section{（4）逆解析の精度}

逆解析の精度を図-16にまとめた。相対誤差を設定荷 重に対する逆解析值とする，相対誤差が土 $10 \%$ 以内のも のが $\sigma_{1}^{\infty}, \sigma_{1}^{\infty}$ では $10 / 12$ データ， $\alpha$ では $2 / 4$ データであっ た. $\alpha$ のデータ数が少ないのは, Case 3 が静水圧状態の ためデータから除外したことによる.このため $\alpha$ につ いては十分な評価はできないものの, 解析では $\sigma_{1}^{\infty}, \sigma_{1}^{\infty}$ と $\alpha$ は $\Delta_{\min }$ から一対で得られるものであるため, $\alpha$ のみ が極度に低精度となる可能性は低いと考える.

\section{7. 結論}

\section{（1）理論及び逆解析方法の妥当性}

試験体側面に載荷した応力状態に対し，逆解析結果の 応力は相対誤差が概ね土 $10 \%$ 以内で得られた， $\alpha$ の精度 もこれに追随すると思われる。 $\pm 10 \%$ 程度の誤差は安定 解析において大きな問題とはならないことから, 提示し た解析理論及び逆解析手法は妥当なものと判断する.

\section{（2）本測定法適用上の留意点}

本測定では二軸状態とした孔軸に直交する面内の初期 応力の比が， $1: 0.35$ （または $2.86: 1$ ）を超えて一方が 卓越する場合には適用範囲外となる。また，初期応力測

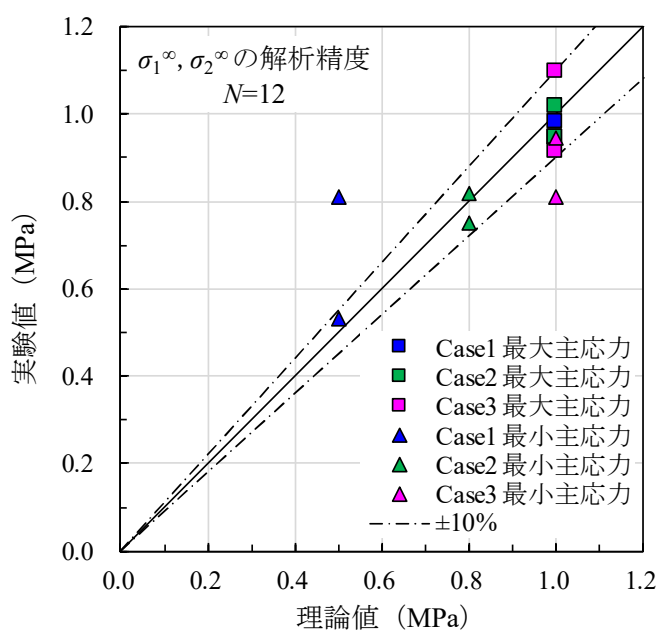

(a) 初期応力 $\sigma_{1}^{\infty}, \sigma_{2}^{\infty}$

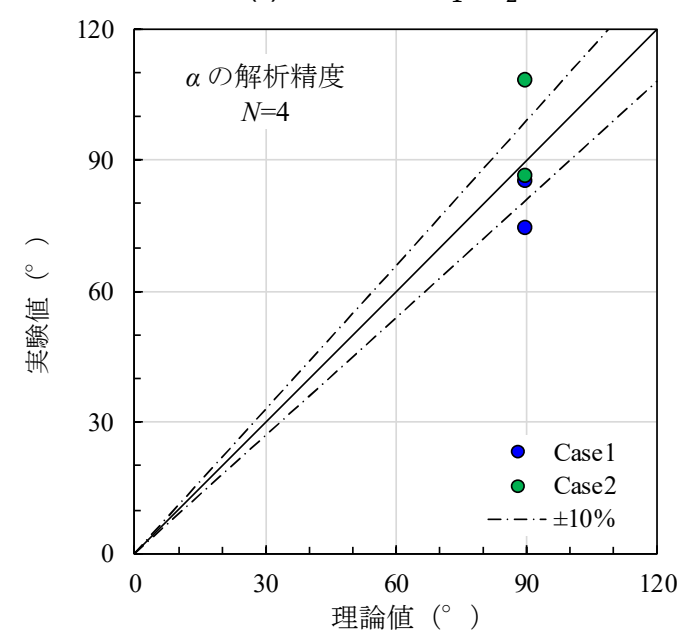

(b) 作用角度 $\alpha$

図-16 各ケースの逆解析精度

定を目的とするボアホールジャッキ試験では, $\Delta p / \Delta u$ の変化をできるだけ詳細に把握するため, 圧力ステップ は $0.1 \mathrm{MPa}$ 程度, 載荷速度は $0.2 \mathrm{MPa} / \mathrm{min}$ 程度以下とする のが妥当である. これらの設定は通常の変形係数を測定 する場合よりも小さい.

\section{(3) 本測定法の位置付け}

本測定法はジャッキ法の一つと位置付けられるが，そ の最も簡易な方法にフラットジャッキ法がある ${ }^{3)}$.これ は岩盤に溝を切削してフラットジャッキを挿入・加圧し, 溝の間隔が変形前の状態に戻った時の圧力をジャッキ面 と垂直方向の初期応力とするものである，本論文での載 荷初期圧 $p_{0}$ はこの考え方と同じであり，ジャッキを二 次元的に拡張適用したものと捉えることができる.

\section{(4) 今後の課題}

本研究における応力解析精度には， $p_{0}$ の読取りが最 も大きな影響を及ぼす。今回の実験では，不連続面は含 まないが粗骨材を含む（非一様な）コンクリート製の試 験体の $p-u$ 曲線をもとに載荷初期段階の特徵を整理した. 
表-A $\Phi(\nu, \beta)$ の值

\begin{tabular}{|r||c|c|c|c|c|c|}
\multicolumn{1}{|c||}{$\beta$} & 0.15 & 0.20 & 0.25 & 0.30 & 0.35 & 0.40 \\
\hline \hline $10.0^{\circ}$ & 0.643 & 0.638 & 0.628 & 0.615 & 0.598 & 0.577 \\
\hline $15.0^{\circ}$ & 0.828 & 0.821 & 0.810 & 0.795 & 0.774 & 0.747 \\
\hline $20.0^{\circ}$ & 0.970 & 0.964 & 0.952 & 0.935 & 0.911 & 0.880 \\
\hline $25.0^{\circ}$ & 1.079 & 1.073 & 1.061 & 1.043 & 1.017 & 0.984 \\
\hline $27.5^{\circ}$ & 1.122 & 1.117 & 1.105 & 1.087 & 1.061 & 1.026 \\
\hline $30.0^{\circ}$ & 1.159 & 1.154 & 1.143 & 1.124 & 1.098 & 1.062 \\
\hline $35.0^{\circ}$ & 1.215 & 1.211 & 1.200 & 1.182 & 1.155 & 1.119 \\
\hline $40.0^{\circ}$ & 1.248 & 1.245 & 1.235 & 1.218 & 1.191 & 1.154 \\
\hline $45.0^{\circ}$ & 1.260 & 1.259 & 1.250 & 1.233 & 1.207 & 1.171 \\
\hline
\end{tabular}

今後，原位置の岩盤に対しても同様に載荷試験を行い, 載荷初期段階の挙動を分析していく必要がある.

謝辞：本研究における載荷実験は，(株)安藤・間 技術研 究所の今井久氏をはじめ原子力部の方々，川崎地質(株) 戦略企画本部の加藤猛部長, 窪島光司氏，知念千佳氏及 び(株)KSK の橋本竜也氏らの協力により実施された．各 位にはこの紙面を借りて深く感謝申し上げる.

\section{付録 関数 $\Phi(\nu, \beta)$ の值}

式(2) の $\Phi(v, \beta)$ の数值は表-A ${ }^{\sigma \sim 9)}$ の通りとなる. 式 (3) の $J_{0}$ 及び $J_{0}^{\prime}$ は $\Delta \theta=0.01^{\circ}$ として Simpson法による数 值積分で求めた. ボアホールジャッキ試験による変形係 数の算定では, $\Phi(\nu, \beta)$ は岩種や岩級に応じて設定され た $v$ と試験器によって定められた $\beta$ から表-A より求め る. 今回の実験での試験体は $v=0.15$, 試験器は $\beta=$ $27.5^{\circ}$ であるため，同表より $\Phi\left(0.15,27.5^{\circ}\right)=1.122$ となる.

\section{参考文献}

1) 地盤工学会 : 地盤調查の方法と解説一二分冊の 2 , 第 10 編 現地計測, 初期地圧の測定, pp.948-980, 丸善, 2013.

2) 土木学会 岩盤力学委員会 編 : 初期地圧測定法の現状 之課題, pp. 3-70, 1992.

3) ベルナール・アマデイ，オーヴ・ステファンソン, 石田 毅（監修），船戸明雄他（訳）：岩盤応力とそ の測定, 京都大学学術出版会, 2012.

4) 金川忠, 日比野敏, 石田毅 : オーバーコアリングに よる 3 次元地圧計測法, 電力中央研究所 - 研究報告, No. 385033, 1983.

5) 三木幸蔵 : わかりやすい岩石と岩盤の知識, pp. 247286, 鹿島出版会, 1978.

6) 地盤工学会 : 地盤調査の方法と解説一二分冊の 2-, 第 8 編 載荷試験, pp. 661-696, 丸善, 2013.

7) 土木学会 岩盤力学委員会編 : 原位置岩盤試験法の指 針, pp. 220-224, 丸善, 2000 .

8) 川久保昌平, 結城則之：等変位孔内載荷試験におけ る弾性厳密解を用いた岩盤変形係数の算定, 土木学 会論文集，No. 666/III-53,pp. 45-53, 2000.

9) 川久保昌平, 原田克之, 川井康右 : ボアホールジャ ッキ試験による地盤変形係数算定の厳密化への取り 組み, 第 46 回地盤工学研究発表会, pp. 475-476, 2011.

10）妻木義彦，山田哲義 : 1 円孔を有する無限板の二，三 の弾 性混合境界值問題, 日本機械学会論文集（第 1 部）， 31 巻， 232 号, pp. 1786-1792, 1965.

11) 森口繁一：2 次元弾性論, pp. 46-51, 岩波書店, 1957.

(Received March 18, 2020)

(Accepted June 25, 2020)

\section{NEW EVALUATION THEORY FOR INITIAL ROCK STRESS BY BOREHOLE JACK TEST}

\section{Shohei KAWAKUBO, Yuji MURAKAMI, Hirokazu NAGASAWA and Kazuo TANI}

It is necessary to evaluate the deformability and initial stresses of rock masses in order to study the stability of cavities and tunnels excavated in deep underground. For initial stress measurement rock masses, in Japan, hydraulic fracturing method and stress release method have been used. However, these measurement methods are costly and time consuming.

On the other hand, borehole jack test is an effective method to measure rock deformabilities. The stiffness of rock masses is calculated from the slope of the linear part of the pressure-displacement curve obtained by the test. In this study, it is theoretically revealed that the initial stresses in rock masses are analized from pressure-displacement curves obtained from a set of tests where three or more loading orientations are assigned.

In this paper, the theory to find initial stress from borehole jack test is derived using exact elastic solution, and the result that its validity is verified by laboratory experiments using large concrete specimens is shown. 